\title{
INDUSTRIALISASI DAN TANTANGANNYA PADA SEKTOR PENDIDIKAN
}

\author{
Arif Unwanullah \\ UNIROW Tuban, Indonesia \\ Email: arifunwanullah@yahoo.com
}

\begin{abstract}
Abstrak: Industrialisasi dan Tantangannya pada Sektor Pendidikan. Sumbangan pendidikan dalam perubahan dan pembangunan masa lalu telah bergeser dengan kemajuan teknoekonomi dan komunikasi. Perubahan yang terjadi telah menggeser tatanan kehidupan dan pandangan masyarakat. Materialisme, kapitalisme, efisiensi, dan efektivitas telah menjadi tujuan dan semangat hidup. Pergeseran pandangan masyarakat telah mengubah pula pandangan keberhasilan dan mutu pendidikan, di mana pendidikan diukur dari keberhasilan dalam keterserapan lulusan dalam dunia kerja, oleh karenanya pendidikan dianalisis dari karakteristik sebagai investasi (capitalinvestment). Pergeseran makna dan tanggung jawab pendidikan mendorong dunia pendidikan melakukan pembaruan dengan alternatif: membangun pembaruan penalaran warganya menuju pemerdekaan dan pendewasaan, pendidikan dilaksanakan secara komprehensif dan bekerjasama dengan semua pihak secara kemitraan, dan membangun visi pendidikan secara komprehensif dan simultan dengan semua pihak.
\end{abstract}

Kata kunci: perubahan sosial, materialistik, modernisasi dan kapitalis

Abstract: Industrialization and its education Sector challenges. Contribution of education has shifted with the progress of technology, economy, and communication. The changes have shifted the society's views. Materialism, capitalism, efficiency, and effectiveness have become of interest and enthusiasm for life. The shift has changed society's view, i.e. the view of success and quality of education, in which education is measured from a rate of the absorption of graduates into labor market, therefore education is analyzed from the characteristics of an investment (capital-investment). A shift in meaning and responsibility of education encourages the education sector to create reformation through these following alternatives: creating new thoughts towards liberation and maturation, implementing education comprehensively and cooperating with all parties in partnership, and creating a vision of education comprehensively and simultaneously.

Keywords: social change, materialistic, modernization and capitalist

\section{PENDAHULUAN}

Sumbangan pendidikan besar terjadi setelah perang yaitu pada masa-masa pembangunan kembali pasca perang dunia II (PD II), pendidikan menyumbang perubahan dari kekacauan jiwa, raga, sosial dan konstruksi budaya pada kemajuan, keselarasan dan mutu kehidupan. Pendidikan juga telah membuka berbagai alternatif dalam perubahan dan pembangunan masyarakat, pendidikan juga mendorong ditemukannya hasil-hasil penelitian sebagai hasil praksis perubahan. Semangat dan slogan perubahan yang disandang pendidikan menjadi tidak bermakna lagi dengan pergeseran paradigma perubahan sosial, makna tatanan nilai-moral masyarakat, dinamika budaya, kemajuan masyarakat, dulu sering dikaitkan 
dengan pendidikan namun demikian kemajuan teknoekonomi dan komunikasi telah menjadi agen perubahan baru dalam kehidupan masyarakat.

Perubahan sosial yang terjadi secara besar-besaran yang dihadapi oleh mayarakat dunia dengan corak, istilah, tempo, sosok, peluang, hambatan, serta makna yang secara historis berbeda-beda. Seperti Industrialisasi, modernisasi, materialisme, konsumerisme, kapitalisme, pragmatisme dan globalisasi menjadi makna dan pola baru dalam tatanan masyarakat, pelan tapi pasti akan menggeser dan merubah pola dan gaya serta kebiasaan hidup dan berpikir masyarakat dunia, tampak berdiri sendirisendiri sesuai dengan eranya, namun demikian satu sama lain tidak pernah lepas dan saling mendukung. Globalisasi yang terjadi dengan ditandai oleh maraknya pertumbuhan industri kapitalisme merupakan salah satu istilah yang sering dikemukakan untuk memaknai dan memahami perubahan secara besar-besaran dan saling mendukung dalam membentuk opini, dan akibat bagi tatanan kehidupan baru masyarakat dunia. Tetapi dengan berbagai variasi maknanya globalisasi yang terjadi tidak memberikan kepuasan kepada semua pihak.

Perubahan yang terjadi tidak hanya sekedar perubahan tata politik dunia atau tata perimbangan kekuasaan militer, atau suatu dinamika ekonomi dan keuangan. Berbagai perubahan sektor yang terjadi dan menjadi sorotan utama ketika orang berdiskusi tentang masyarakat mutakhir dengan menggunakan istilah-istilah kunci seperti industri, kapitalisme, atau globalisasi. Namun demikian perubahan yang sedang terjadi secara besar-besaran merupakan perubahan yang biasa disebut sebagai kebudayaan, nilai-nilai, selera, gaya hidup, ideologi, solidaritas sosial, gairah, identitas sosial, dan sebagainya.

Indonesia sebagai bagian dari mayarakat dunia tidak kebal dari gelombang perubahan besar-besaran itu. Krisis ekonomi dan pertumbuhan gerakan pro-demokrasi (reformasi) itu dapat diambil sebagai bagian dan hasil proses sejarah sosial panjang dan kompleks yang bergerak pada skala dunia. Nasib Indonesia selanjutnya juga tidak sepenuhnya di tangan bangsa Indonesiaapalagi di tangan segelintir elite politik di Jakarta, tetapi merupakan hasil berbagai paduan dan konflik antar berbagai kekuatan sosial yang sebagian lokal, sebagian nasional, tetapi juga sebagian tidak kecil bersifat global.

Pranata sosial pendidikan di Indonesia juga terjerat dan sekaligus tergerak dalam berbagai arus perubahan sosial yang menggelisahkan dan membingungkan ini. Pendidikan telah kehilangan jiwanya, dulu sebagai kekuatan pencerahan, penyadaran, menantang kreativitas dan inovasi. Filsafat yang dianutnya, proses maupun integritas para pelaku pendidikan tak mampu lagi sebagai kekuatan perubahan kemajuan warga bangsa namun telah tergerus oleh tuntutan kemajuan ekoteknologi dan komunikasi yang mengarahkan mentalitas bangsa dan warga dunia pada pandangan materialis sehingga ukuran mutu keberhasilan hidup adalah materialistik. Pendidikan pada masa ini adalah pendidikan yang memiliki unsur-unsur perubahan, cepat, efektif, efisien, industri, teknologi, komunikasi, informasi, dunia kerja dan 
terampil bukan lagi pendidikan yang memerdekakan (Freir, 2002) atau pendidikan sebagai proses pemanusiaan manusia atau humanisasi (Driyarkara, 1980).

Perkembangan globalisasi berdampak pada pola pikir dan tatanan kehidupan, dimulai dari kesepakatan dan kerjasama seperti GTO, AFTA dan MEA namun demikian yang menjadi pertanyaan adalah apakah kita telah siap, baik kemampuan maupun peluang dalam bersaing dalam dunia kompetisi.

Uraian berikut memaparkan beberapa pengamatan, dan berupaya memahami beberapa kecenderungan yang terjadi dalam bidang pendidikan formal di Indonesia dalam periode dan proses perubahan yang ditandai oleh kuatnya watak industrialisasi global. Asumsi dasar yang digunakan dalam pembahasan berikut ini dapat dirumuskan sebagai berikut: proses industrialisasi pendidikan sudah dan sedang terjadi di Indonesia, proses ini menjadi gencar dan semakin marak pada tahun-tahun mendatang.

\section{OPTIMISME DAN PESIMISME}

Sikap dan prasangka seseorang selalu menentukan objek dan sifat pembahasannya. Apa yang terjadi dalam dunia pendidikan di Indonesia seperti di banyak tempat lain, telah dialami dan dibahas secara berbeda-beda oleh berbagai kelompok dalam masyarakat. Dua di antaranya saling bertolak belakang.

Di satu pihak, kita menjumpai mereka yang menyaksikan nasib pendidikan dengan wajah muram, dan membahasnya dengan penuh ratapan, penyesalan kalau bukan kemarahan. Antara lain, mereka mengatakan bahwa mutu pendidikan kita semakin merosot (dengan berbagai ukuran dan penyebab yang tidak seragam dalam berbagai uraian mereka) hal-hal seperti industrialisasi atau globalisasi dianggap sebagai sebuah ancaman atau musuh pendidikan.

Di pihak lain, juga dijumpai yang dengan giat membuka berbagai wilayah baru dalam dunia pendidikan. Dengan bersemangat mereka menyebarkan berita seakan-akan dunia pendidikan telah menikmati sebuah kebangkitan baru dan kemungkinankemungkinan pertumbuhan yang tak terbayangkan sebelumnya. Teknologi informasi, jaringan kerja antar lembaga pendidikan mancanegara, serta semakin meluasnya kesempatan belajar bagi kaum muda usia sekolah dari berbagai latar belakang sosial dikemukakan sebagai beberapa contoh kemajuan terpenting yang pantas dirayakan dan disyukuri dalam bidang pendidikan. Sejumlah angka statistik dikutip dan dipajang dalam tabel dan grafik.

Kontras kedua pandangan itu sengaja dibuat agak kasar dan berlebihan untuk memperjelas rentang perbedaan sikap yang tumbuh dalam masyarakat terhadap perubahan dunia pendidikan di Indonesia. Betapa pun keduanya bertolak belakang, mereka sama-sama sepakat bahwa dunia pendidikan kita telah dan masih sedang mengalami perombakan besar-besaran yang tidak selalu dilaksanakan dengan kesepakatan semua pihak. Bahkan kadangkadang di luar kendali siapa pun, walau dimanfaatkan oleh beberapa pihak secara tidak merata.

Dari pandangan-pandangan demikian manakah yang benar? bukan soal benar atau 
salah itu sendiri yang menjadi pokok bahasan tetapi pada setiap perubahan sosial ada sebagian pihak yang memperoleh keuntungkan dan sebagian pihak memperoleh kerugian. Sebagaimana Noeng Moehadjir (2001) mengatakan Jika ada inovasi dengan kekuatan tinggi maka perubahan sosial bersifat progresif sebaliknya jika ada inovasi tidak memiliki kekuatan tinggi maka perubahan sosial akan berjalan serkiler bahkan tidak mustahil akan menjadi mati. Hal yang sama terjadi dalam dunia pendidikan, Pihak yang dirugikan cenderung membesar-besarkan atau mempersoalkan hal-hal yang di masa lampau yang indah, Mereka tidak rela dan cenderung bernostalgia ke masa lampau yang tak mungkin kembali. Pihak yang diuntungkan oleh perubahan itu cenderung membesarbesarkan atau hanya mengamati hal-hal yang lebih baik yang dijanjikan oleh perubahan yang sedang berlangsung. Kadang-kadang karena asyik, mereka tidak kritis terhadap proses yang masih baru terjadi dan belum sepenuhnya teruji, serta cenderung mengabaikan biaya sosial dan akibat-akibat tak resmi atau sengaja atau berjangka panjang yang tidak segera tampak kasat mata.

Walau berisiko menyederhanakan masalah dan berisiko akan disalahpahami, perbedaan kedua sikap dengan dua cara memahami pendidikan yang sangat kontras. Kaum pesimis cenderung mengartikan pendidikan pertama-tama dan utama pada persoalan nilai-nilai kemanusiaan yang luhur, dedikasi, kreativitas, otonomi individu, kebenaran, mungkin juga kesejahteraan umat manusia secara universal. Semua itu jelas serba indah dan mulia. Tetapi, semua yang indah dan mulia itu tidak tiba-tiba hadir di muka bumi dan di luar proses sejarah sosial. la merupakan produk dari sebuah sejarah yang sering kali berlumuran darah, penuh dengan korupsi dan imoralitas. Kaum optimis menyambut perubahan besar-besaran (industrialisasi) dalam dunia pendidikan mutakhir cenderung memahami persoalan pendidikan terutama sebagai persoalan angka-angka, hal-hal kebendaan lembaga, proses interaksi indrawi, dan penerapan pengetahuan atau keterampilan dalam dunia kerja industri.

Sekarang pendidikan lebih jauh lebih tersebar dan terjangkau oleh berbagai kelompok masyarakat di berbagai pelosok dunia. Perbedaan kesempatan bersekolah antara jenis kelamin, atau antara desa dan kota sudah jauh lebih baik. Tidak salah jika ini dianggap sebagai sebuah proses pemerataan dan demokratisasi pendidikan. Proses belajar mengajar juga jauh lebih fleksibel, bahkan menarik berkat berbagai teknologi informasi. Belajar tidak lagi harus bersusahpayah, memencilkan diri, bertahan dalam kebosanan, atau mengerjakan sesuatu berulang-ulang, lamban dan rumit. Dengan komputer dan internet, pendidikan menjadi penuh warna dan pesona.

Semua persoalan itu tidak salah, tetapi proses pemerataan pendidikan juga telah disertai perbedaan jenjang dan gengsi dalam berbagai bentuk baru. Ternyata kemudahan, ketepatan, dan kecepatan proses olah informasi tidak sama dengan peningkatan kecerdasan, kreativitas, apalagi kepekaan, anak belajar terhadap masalah-masalah sosial. Malahan berbagai lembaga pendidikan padat teknologi tinggi telah menumbuhkan sebuah ketergantungan baru 
pada teknologi yang sangat mencemaskan. la juga menumbuhkan penyempitan sikap, minat, serta cakrawala pemahaman persoalan menjadi serba singkat, cepat, dan instrumental.

\section{GLOBALISASI DAN INDUSTRIALISASI PENDIDIKAN}

Sesungguhnya gambaran perbedaan di atas tidak seharusnya menjadi sebuah pertentangan ekstrem yang saling meniadakan. Kapan pun dan di mana pun pendidikan merupakan kedua-duanya: halhal yang bersifat nilai, budaya dan etika serta hal-hal yang bersifat materi, kelembagaan, kebendaan, serta duniawi. Tetapi, sejarah masyarakat tidak pernah secara netral menempatkan keduanya sama penting dan secara terpadu.

Sejak pemerintahan kolonial Belanda membuka sekolah-sekolah untuk kaum pribumi sebagai bentuk politik etis (untuk kepentingan mencetak pegawai pemerintah dan tenaga murah), pendidikan formal tidak pernah terlepas dari kepentingan politik ekonomi kaum yang sedang berkuasa secara politik, ekonomi, maupun budaya. Lebih tegasnya, sekolah tidak pernah semata-mata atau terutama dimaksudkan sebagai upaya "mencerdaskan kehidupan bangsa" atau memajukan ilmu pengetahuan dunia secara abstrak dan universal, atau mensejahterakan rakyat jelata. Pendidikan, seperti halnya pranata sosial apa pun yang lain (agama, ekonomi, politik, kesenian, atau bahkan keluarga) selalu berlangsung dengan unsurunsur yang saling bertentangan. Tetapi telah terjadi perubahan penting dan makro dalam beberapa tahun belakangan, bukan dalam hal kiblat atau tujuan, tetapi dalam proses dan perangkat kerja yang selanjutnya berpengaruh pada tujuan pendidikan.

Selama bertahun-tahun pendidikan di Indonesia bertumbuh dengan modal piranti keras (kelembagaan, birokrasi, sumber dana dan daya) serba pas-pasan, tetapi semua itu diimbangi oleh modal non material (semangat, dedikasi, selain kebanggaan, gengsi lokal serta nasional, juga ilusi dan ideologi) yang tinggi. Semua ini mulai mengalami perubahan besar-besaran selama lebih dari 30 tahun masa pemerintahan orde baru yang menempatkan pertumbuhan ekonomi dan industri sebagai prioritas terpenting. Pertumbuhan pranata pendidikan pada segi badaniah menjadi penting-bersamaan dengan mekarnya militerisme yang memulyakan otot kekar dan kejahatan-dan ditunjang oleh berbagai bantuan dari negeri-negeri blok barat yang menjadi sekutu orde baru dalam perang dingin.

Salah satu kelanjutan yang tidak dapat dihindari dari proses semacam itu adalah semakin terkaitnya proses pendidikan di berbagai pelosok tanah air dengan apa yang terjadi di mancanegara. Industrialisasi Indonesia sendiri-seperti halnya legitimasi. Hal ini dapat diamati bukan saja dalam bentuk besarnya beasiswa yang tersedia bagi akademisi Indonesia untuk melanjutkan studi ke negeri-negeri non komunis. Juga sebaliknya kunjungan dari berbagai akademisi dari negara-negara itu untuk membantu pendidikan di Indonesia. Sebagian juga merupakan hasil usaha meminta-minta dari pihak Indonesia. Jadi, tidak dapat dikatakan bahwa yang terjadi adalah imperialisme atau neo-kolonialisme 
barat dalam pengertian pemaksaan sepihak di bidang pendidikan.

Pendidikan di Indonesia tidak saja mengalami proses Industrialisasi tetapi juga internasionalisasi. Ada perbedaan penting yang layak disimak di antara proses itu dalam bidang ekonomi dan proses serupa dalam bidang pendidikan. Secara lebih khusus, perbedaan yang penting terjadi pada status dan nasib perusahaan-perusahaan dagang dengan status atau nasib lembaga-lembaga pendidikan. Bagi perusahaan besar, globalisasi biasanya merupakan peluang, rejeki, dan impian yang menjadi kenyataan. Tanpa globalisasi, upaya dagang dan akumulasi modal sering kali terbentur oleh batas-batas kedaulatan, birokrasi, atau sentimen kebangsaan-kenegaraan. Globalisasi dalam bentuk pertumbuhan bidang informasi, komunikasi, dan transportasi merupakan sebuah peluang atau jembatan emas bagi pemodal untuk menembus berbagai batas ruang dan waktu bagi akumulasi modal dan perbesaran laba sebesar-besarnya.

Seperti telah kita ketahui bersama semua ini menjadi salah satu sumber keunggulan para pemodal besar jika dibandingkan dengan kaum buruh dan birokrasi negara, yakni kemampuan melompat dari suatu wilayah (lokal, negara atau benua) ke wilayah lain. Dengan demikian, ia tidak harus bertahan dengan satu kondisi hubungan industrial di satu lokasi dengan kelompok buruh atau peraturan birokrasi yang menjengkelkan. Kemampuan berpindahpindah ini atau mobilitas, membuat pemodal sering kali dibutuhkan dari pada membutuhkan baik buruh maupun birokrasi negara tertentu. Kesenjangan serupa barangkali dapat dibandingkan dengan kesenjangan gender pada keluarga tradisional kelas menengah: kaum suami menguasai dunia publik dan memiliki mobilitas tinggi, sementara kaum istri terikat pada dunia domestik. Itu sebabnya berita hengkangnya modal dan pemodal untuk menanamkan kembali modal di negara yang sedang sakit-sakitan, disertai sejumlah janji, perlakuan istimewa, dan kemanjaan supaya mereka kerasan.

Hingga sekitar pertengahan dasawarsa 1990-an, mahasiswa dari Asia yang belajar ke negara-negara industrial di Barat dianggap lebih rendah daripada mahasiswa lokal. Para mahasiswa pendatang ini mungkin saja termasuk yang paling cerdas di kelas, tetapi mereka tetap dianggap sebagai makhluk yang berbeda dan tidak akan pernah menjadi sama atau setara dengan anak-anak Barat sendiri. Anak-anak Asia ini dianggap dan sering kali juga menganggap diri sendiri sebagai kaum elite dari negeri terbelakang yang beruntung karena mendapatkan pencerahan dari Barat, sebuah warisan peradaban paling unggul di dunia. Mereka harus belajar pandai-pandai berbahasa bekas penjajah ini, mereka harus paham sopan santun ala Barat, dan memahami seluk-beluk bekerjanya birokrasi di lembaga pendidikan Barat agar mampu menamatkan perkuliahan dan mendapatkan gelar bergengsi di negara bekas penjajah.

Anak-anak Asia mendapat perlakuan istimewa dalam berbagai birokrasi pendaftaran dan perkuliahan. Gejala ini tidak merata, dan kini lebih terasa di negeri Australia misalnya, dari pada Amerika Serikat atau Eropa. Tetapi sebagai gejala umum dia dapat dijumpai di berbagai tempat itu 
dengan kadar berbeda. Seorang rektor sebuah Universitas besar di Australia barubaru ini menyatakan dengan tegas bahwa pada zaman ini pendidikan merupakan salah satu industri terbesar dan terpenting di dunia. Jadi pendidikan dapat diseret berdampingan dengan industri komputer, telepon genggam, tekstil, minyak, kalau bukan bursa saham. Rektor yang sama dengan rendah hati mengatakan bahwa universitas tidak mampu mengubah dunia dan membuatnya lebih baik.

Gejala makro itu menjelmakan diri secara keseharian dalam suasana perkuliahan di kelas-kelas di berbagai tempat di dunia. Hukum pasar yang berlaku di antara pesaing industri pendidikan pada tingkat global juga merebak pada tingkat lokal di kampus dan bahkan di ruang kelas serta bermuara pada interaksi dosenmahasiswa. Sesuai dengan hukum penawaran-permintaan, fakultas atau jurusan yang laris dianak-emaskan, misalnya ekonomi, bisnis, manajemen, kedokteran, teknik, atau komputer. Adapun bidang pendidikan seperti filsafat, bahasa, sejarah, pendidikan, atau etika diancam tutup karena kurangnya peminat. Para mahasiswa sendiri berbondong-bondong memilih bidang studi yang laris bukan berdasarkan minat dan bakat tetapi prospek pasar kerja yang tersedia sesuai dengan lulusan pendidikan. Di masing-masing jurusan yang kering dan kurus, terjadi persaingan dan ancaman serius terhadap status kepegawaian dosen yang kuliahnya kurang diminati mahasiswa. Kelas kecil sama dengan toko yang sepi. la harus ditutup karena ia membebani ongkos lembaga yang bersangkutan dan dosennnya diberhentikan atau diminta mengajar bidang lain yang bukan minatnya tetapi punya nilai pasar.

Di hampir semua kampus di negaranegara industri, setiap fakultas dihargai dan hanya bisa bertahan hidup apabila berhasil mendatangkan sejumlah mahasiswa peminat dan pembayaran uang kuliah. Akibatnya, setiap dosen yang bekerja di fakultas itu juga dihargai menurut kemampuannya "menjual" perkuliahan yang dihitung menurut jumlah mahasiswa. Semua ini bisa berakibat buruk apabila tidak ada mekanisme kontrol kualitas secara kelembagaan. Untuk menarik mahasiswa sebanyak-banyaknya, para dosen bisa saja berlomba membuat pelajaran seringan mungkin, ujian semudah mungkin, nilai semurah mungkin, pekerjaan rumah sesedikit mungkin dengan lelucon dan bukan analisis kritis. Promosi pangkat, status, bonus tahunan, cuti, dan sejumlah hak kerja sang dosen ditentukan seminimal mungkin, dan beban tugas mereka melimpah. Semua ini demi menekan ongkos produksi pendidikan. Akibat berikutnya, para dosen ini terlalu sibuk mempertahankan status kepegawaiannya, tak pernah punya waktu cukup untuk berinteraksi dengan mahasiswa di luar jam kuliah, atau bahkan untuk mengembangkan diri secara intelektual.

\section{KETIDAKJELASAN MASA DEPAN.}

Perubahan yang digambarkan secara sederhana di atas berlangsung dalam jumlah besar-besaran dan dinamika yang jauh lebih kaya warna serta nuansa daripada yang dapat digambarkan di sini. Tujuan penggambaran itu sederhana, yakni menggarisbawahi sebuah kondisi mutakhir yang bersifat global yang menjadi konteks 
masa kini bagi lembaga dan watak pendidikan tinggi di Indonesia. Gambaran di atas juga sekaligus menjadi sebuah peringatan dalam bentuk contoh apa yang mirip bisa terjadi di Indonesia di masa depan yang dekat, apabila stabilitas politik dan sosial Indonesia membaik, perekonomian pulih dan industrialisasi melaju dengan gencar.

Suka atau tidak, sebuah proses besarbesaran (katakanlah industrialisasi atau kapitalisme global) memukul telak sebuah tata sosial dan tradisi pendidikan yang pra industrial, atau proto-industrial, atau industri-awal di Indonesia dan memaksakan sebuah tata sosial dan tradisi baru yang semakin industrial dan global. Proses ini bukan baru terjadi sekarang. la sudah mulai gencar berkembang hingga Indonesia semakin tercekam dalam kancah pasar kapitalisme global yang ditandai oleh kebijakan ekspor non-migas, swastanisasi, dan demiliterisasi. Pada mulanya proses ini berlangsung gencar dalam bidang perdagangan. Tetapi segera melebar ke bidang-bidang lain dalam tempo dan irama yang berbeda-beda: pendidikan, politik, keluarga, kesenian, dan sebagainya.

Indonesia yang semula lebih banyak bertumpu pada birokrasi yang berpusat pada elite politik yang berkuasa digeser oleh sebuah kompetisi global yang berpusat pada pasar yang juga tidak pernah sepenuhnya bebas dan adil. Apa yang terjadi di Indonesia dapat diibaratkan sebagai sebuah proses perubahan besar-besaran dari negara yang menganut sistem perekonomian komando partai seperti komunis menuju ke pasar setengah bebas. Politik dan birokrasi menjadi panglima (sementara jenderal dan panglima menjadi politikus dan pengusaha). Pendidikan menjadi sebuah ritual propaganda dan produksi slogan sebagai tuntutan industrialisasi kapitalisme global.

Apakah perubahan demikian sebagai berkah atau bencana? Yang terjadi adalah bergantinya berkah lama dengan berkah baru dan lenyapnya bencana lama digantikan bencana baru. Dampaknya berbeda-beda bagi berbagai kelompok sosial. Yang jelas dengan merosotnya campur tangan politik dalam pendidikan, tidak berarti pendidikan menjadi serba indah, merdeka, dan otonom. Dalam perubahan yang sedang berlangsung, hukum pasar mendikte dinamika pendidikan dengan berbagai eksesnya.

Bagi sejumlah pengamat pendidikan, dunia pendidikan di negara-negara kaya yang sudah lebih suntuk dengan industrialisasi seakan-akan menjadi teladan dan impian. Bagi sebagian akademisi Indonesia serta para orang tua Indonesia yang kaya, pendidikan tinggi di luar negeri ini menjadi alternatif pendidikan yang lebih menjanjikan dari pada yang tersedia di Indonesia. Sebuah angan-angan kedaluwarsa biasanya berarak dalam pandangan mereka tentang kehebatan pendidikan luar negeri. Di sana berbagai karya ilmiah dihasilkan. Kelancaran pengajaran dan kelimpahan sumber daya menjadi salah satu legenda yang menggiurkan para akademisi Indonesia, seakan-akan di sana otonomi kampusbersamaan dengan kebebasan berpendapat dan belajar-menjadi sebuah kenyataan lumrah; kreativitas dan segala nilai peradaban yang agung seperti disebutkan pada bagian awal tulisan ini seakan-akan 
berkelimpahan, padahal di Indonesia menjadi barang langka. Mitos semacam ini merupakan salah satu bentuk keberhasilan ideologi pasca-kolonial Barat yang bisa dijual untuk menarik minat anak-anak muda Asia agar bersekolah dan membayar uang sekolah di mancanegara.

Di sini ironisnya, di awal tulisan ini dibedakan dua kelompok sikap yang ekstrem dalam memandang perubahan dalam pendidikan. Salah satunya kaum pemuram dan pesimis-suka meratapi merosotnya sistem pendidikan di tanah air dengan membatasi pengertian pendidikan pada halhal non material (nilai-nilai sosial, intelektual, etis, dan kreativitas individual). Biasanya kelompok yang sama memandang pendidikan di Barat sebagai sebuah surga akademik. Padahal, justru di Baratlah industrialisasi berlangsung secara menggebu-gebu, juga industrialisasi pendidikan. Di Barat, hukum pasar berlaku untuk banyak bidang kehidupan sosial, juga dalam pendidikan melampaui skala yang bisa dibayangkan di Indonesia.

Uraian di atas menunjukkan bahwa globalisasi menjadi semakin kabur walau tidak sepenuhnya lenyap batasan dalam/ luar negeri. Industrialisasi pendidikan bukan sebuah pilihan yang bisa dipeluk atau ditolak secara bebas. la sudah dan masih sedang menjadi bagian dari tulang sumsum praktek pendidikan di Indonesia. Karena proses ini baru belakangan berlangsung secara gencar, tidak sedikit yang kaget-kagetan. Misalnya semakin lumrahnya sekolah dan pendidikan tinggi dijajakan di iklan dan pusat-pusat perbelanjaan, di antara iklan dan toko yang berjualan shampo, parfum, celana jeans, dan kaset. Ini sama barunya dengan gejala pengiklanan industri warta berita baik cetak maupun televisi. Orang membuat berita bukan karena ada suatu peristiwa penting, dan orang mengikuti berita bukan karena butuh informasi tentang dunia. Yang terjadi adalah orang berjualan berita dan publik membeli hiburan atau gosip.

Dalam dunia pendidikan sebelumnya memang sudah ditanamkan semangat kapitalisme dan hukum pasar, walau pada saat itu patrimonialisme dan feodalisme politik masih menjadi payung besarnya. Bentuknya yang paling konkret adalah sistem kredit. Proses pendidikan dipecahpecah menjadi satuan unit perkuliahan (atau penelitian, atau kerja laboratorium, atau tugas praktek lapangan) dan dijualbelikan secara eceran. Setiap mahasiswa bekerja dan dinilai secara individual dan dihargai secara kumulatif dalam sebuah medan kegiatan yang bersifat kompetitif. Hal yang sama berlaku untuk sebuah medan kegiatan yang bersifat kompetitif. Hal yang sama berlaku untuk sistem penghargaan terhadap kinerja dosen. Juga kinerja fakultas dan jurusan. Proses ini akan dikembangkan secara lebih terbuka dan menyeluruh dalam bentuk otonomi kampus bersamaan dengan melenyapnya otonomi kerja intelektual.

Bila otonomi kampus dilancarkan secara sungguh-sungguh dan berlangsung sukses, maka sulit dibendung, apalagi dilawan, melebarnya sebuah kesenjangan sosial dan intelektual yang mencolok. Akan ada sejumlah universitas mahakuat dan mahakaya, ada yang mahalemah dan mahamiskin. Ada bidang studi yang supergiat, gemilang, bergengsi, selain kaya raya, dan ada sejumlah bidang studi yang sangat merana, atau bahkan menjadi punah. 
Para dosen, dan peneliti akan menempati status, gaji, dan kekuasaan birokrasi kampus dalam sebuah jenjang yang tajam. Sebuah kontradiksi dan konflik kelas akan menjadi lebih gamblang.

Proses transformasi sosial besar-besaran yang diuraikan di atas tidak sepenuhnya negatif atau positif bagi semua orang secara seragam. Tetapi dikarenakan kualitas dan kategori pendidikan yang diperoleh pada jenjang pendidikan, jurusan dan bidang tertentu bisa jadi merupakan proses pembebasan dari beban yang tak pernah dibutuhkan: belajar indoktrinasi, pelajaran atau budaya menghafal atau berbelitnya birokrasi pendidikan yang rasialis dan feodalis.

Dua pertanyaan berikut tidak pernah mudah dijawab dan juga tidak mudah untuk diabaikan: Pertama, sejauh mana perbaikan nasib dan kekuasaan kaum kapitalis dan kelas menengah profesional itu punya relevansi dan konsekuensi bagi proses panjang demokratisasi yang lebih luas? Sebagaimana Slamet dan Sutarjo; Noeng Muhajir (dalam Noeng Moehajir, 2001) pengelolaan pembangunan dapat dilakukan dengan partisipasi masyarakat dengan determinan tiga fungsi opinion leader inovatif terdiri: 1) fungsi pembinaan (partisipasi, empati, pemanfaatan media komunikasi, pandangan kosmopolit, dan integrasi sosial); 2). fungsi pengarahan (motivasi, aspirasi, keberanian mengambil risiko dan kreativitas) 3) fungsi tanggap disesuaikan dengan program pembangunan pedesaan. Dalam proses pembangunan pendidikan kaitannya dengan perubahan secara revolusioner industrialisasi bidang pendidikan perlu melibatkan berbagai pihak.
Pertanyaan kedua, Kalau proses industrialisasi akan membawa Indonesia ke keadaan yang tidak lebih baik, atau bahkan lebih buruk, apa pilihan lain yang tersedia? Sejauh mana industrialisasi pada umumnya dan industrialisasi pendidikan pada khususnya dapat ditolak atau diambil alih secara sepotong-sepotong sesuka kita? Sejarah membuktikan bahwa proses pembangunan dengan mengimpor modernisasi Barat secara sepotongsepotong sesuai misi dan visi penguasa banyak negara yang mengalami kegagalan. Mengimpor ilmu dan teknologi Barat tetapi menolak filsafat, budaya dan etika dominan Barat yang dianggap terlalu individualis, sekuler, kapitalis. Ada yang meminta-minta modal asing dan kecanduan utang luar negeri. Tetapi menolak gagasan politik oposisi dan demokrasi liberal. Atau gagasan sosial (seperti feminisme dan hak asasi), dan ekonomi (seperti hak berserikat dan pemogokan). Tampaknya hingga kini berbagai usaha seperti itu gagal, atau banyak gagalnya. Proses perubahan sosial sulit dipilah-pilah karena pada dasarnya kehidupan sosial itu punya tali-temali yang erat, walau tidak selalu menyebar secara seragam dan merata ke berbagai wilayah di dunia.

\section{SIMPULAN}

Pertama Pendidikan memiliki tugas untuk membangun pembaharuan penalaran warganya menuju pemerdekaan dan pendewasaan, oleh karenanya upaya-upaya pendidikan yang merangsang penalaran menjadi visi yang urgen. Sehingga pengajaran untuk bidang-bidang filsafat, sejarah, humaniora kesusastraan dan bahasa 
menjadi bagian yang tidak ditinggalkan lagi dalam pengalaman warga pembelajarnya. Oleh karenanya praksis pendidikan seperti menulis, book report, observasi ceramah, diskusi, debat-debat klasik antar peserta didik dan peserta didik dengan pendidik menjadi kegiatan yang ideal dalam menumbuhkan keberanian berpendapat dan mengemukakan ide-ide kreatif. Penalaran akan tumbuh dan berkembang dengan metodologi yang mendukung proses dan menghargai tahapan pertumbuhan penalaran dengan bimbingan yang kondusif dan dinamis berbagai pihak dalam pendidikan.

Kedua Pendidikan dilaksanakan secara komprehensif dengan bekerjasama antar berbagai bidang, penalaran dan kepekaan terhadap perubahan tidak akan terjadi jika hanya dilakukan oleh bagian-bagian, oleh karenanya pendidikan juga harus bekerjasama dengan semua pihak baik antar lembaga pendidikan akan tetapi juga dengan dunia kerja dan industri perlu dilakukan. Pada akhirnya masyarakat juga memiliki harapan bahwa mutu pendidikan tergantung pada kemampuan lulusannya dalam memasuki dunia kerja oleh karenanya pendidikan harus mampu bekerjasama dengan dunia kerja utamanya dunia industri dan teknologi dengan asas kemitraan yang saling menguntungkan.

Ketiga Pendidikan harus mampu membangun visi pendidikan secara menyeluruh baik secara horizontal dan vertikal dari berbagai jenis tingkatan pendidikan (komprehensif dan simultan) sehingga keterkaitan dan keterpautan antar pendidikan dapat menjamin dinamisasi perkembangan dan mutu kualitas saling mendukung dalam suasana dunia yang berubah.

\section{DAFTAR PUSTAKA}

Agus Suwignyo, (2008) Pendidikan tinggi \& goncangan perubahan. Yogyakarta: Pustaka Pelajar.

Driyakara, N. (1980) Driyakara tentang pendidikan. Yogyakarta: Kanisius.

Everet Reimer. (2000) Matinya sekolah (saduran oleh $m$. soedomo judul asli school is dead) Yogyakarta: PT Hanindita Graha Widia.

Ira Shor dan Paulo Freire. (2001) Menjadi guru merdeka petikan pengalaman. (terjemahan a. nasir budiman judul asli a pedagogi for liberation dialogues on transforming education). Yogyakarta: LKIS

Noeng Muhadjir. (2001) Identifikasi faktorfaktor opinion leader inovatif bagi pembangunan masyarakat (suplemen: tes inventori, teori \& konstruksi. Yogyakarta: Penerbit Rake Sarasin.

Paulo Freire (2002) Kehidupan, karya dan pemikirannya. Yogyakarta: Pustaka Pelajar.

Suyanto dan Djihad Hisyam. (2000) Refleksi dan reformasi pendidikan di indonesia memasuki milenium III. Yogyakarta: Adicita Karya Nusa.

Tilaar, H.A.R. (1998) Beberapa agenda reformasi pendidikan nasional dalam perspektif abad 21. Jakarta: Terra Indonesia. 